\title{
Special Autonomy and Poverty in Special Region of Yogyakarta
}

\author{
D Harsono $^{1}$, P Yuanjaya ${ }^{2}$ \\ 1,2, Department of Public Administration, Universitas Negeri Yogyakarta, Yogyakarta \\ Indonesia \\ ${ }^{1}$ dwiharsono@uny.ac.id, ${ }^{2}$ pandhu@uny.ac.id
}

\begin{abstract}
This paper aims to analyze poverty concerning the special autonomy program of Yogyakarta toward the utilization of special autonomy funds to reduce its rate. This type of research is a qualitative study with a descriptive approach. The data source is compiled from the literature derived from the journal, scientific report and various other documents produced by different agencies related to poverty policy and special autonomy in Yogyakarta. The data collection techniques used in this study are documentation. At the same time, the analysis was done by the coding method and content analysis. The results showed that the regional government of Yogyakarta allocated autonomy funds in the activities designed and approved by the Ministry of Finance, considering the privileges received is a specific allocation fund of the central government. Related to poverty rate that is still high in Yogyakarta, programs funded with special autonomy funds are expected to provide a leverage effect to poverty alleviation. However, this leverage effect has not successfully appeared in the implementation of the autonomy program in Yogyakarta.
\end{abstract}

Keywords: special autonomy, poverty, poverty alleviation, a leverage effect

\section{INTRODUCTION}

Poverty in Indonesia is a problem that is not resolved. The poverty rate is still high, which is 25.14 million inhabitants or 9.22 percent of the total population [1]. Moreover, the World Bank estimates that there is 20.19 percent of Indonesia's people in the poverty line, it is vulnerable again under the poverty line when inflation and stabilization of the economy are not maintained [2]. The magnitude of poverty in Indonesia is also a significant cause of inequality at 0.38 in 2019 [1]. Poverty has a direct impact on prosperity affecting the fulfilment of basic needs in society [3], and further causes social vulnerability [4].

There have been many central government-issued policies (top-down) to improve people's welfare. The intervention of such conditions comes from many ministries/institutions. It involves the stakeholders of each region directly or indirectly in those programs, such as Poor Student (BSM), Family Wishes Program (PKH), a national program of Masyarakat-Mandiri (PNPM-Mandiri), the People's Business credit program (KUR), Indonesia Smart Card (KIP), Indonesia Health Card (KIS), and Family prosperous card (KKS). However, such remediation attempts are slow, even stagnant as the data described earlier. The depth and severity index of poverty is increasing annually [1]. That is, more and more Indonesians are struggling only to meet their basic needs (worthily).

Several factors cause policy optimization-first, the occurrence of policy uniformity in each region. The social background, economy and geography of each area in Indonesia are very 
diverse that will determine the success of policy intervention. Secondly, the existence of a robust and sectoral ego in each government agency led to the overlap of the program [5]. Thirdly, the problem is on the policy side that impresses project-orientated without an evaluation, and the continuity of the program is clear. Welfare improvement policies are also familiar with social aid imagery that increasingly increases the dependence of society [6].

The vast opportunities in alleviating poverty exist in special autonomy policies in some areas. The programs provide more flexibility to local governments in regional management and provide more fiscal space through special autonomy funds to maximize existing potential. Five areas gain special autonomy in Indonesia, namely: The Province of Aceh, Papua province, West Papua province, the special region of Jakarta Capital and Yogyakarta region.

The granting of different autonomy on the five provinces began after the 1998 reform era. Aceh province became the first to be a special autonomous region with the enactment of law No. 44 the year 1999. The implementation of privileges of the province of Aceh special and strengthened by Act No. 11 the year 2006 concerning Aceh government. Papua province became an autonomous region with the enactment of Law No. 21 of 2001, while West Papua province followed seven years later with the issuance of Perpu No. 1 the year 2008 which revised the law of 21 years 2001 that added West Papua as a special autonomous region. DKI Jakarta became a special autonomous region under Law No. 29 of 2007 about the special area of Jakarta Capital as the capital of the unitary Republic of Indonesia. Finally, Yogyakarta became a special autonomy after the issuance of Law 13 years 2012 about the privileges of Yogyakarta special region.

Special autonomy was enforced in the previous five areas with varying reasons. Aceh and Papua have similarities in terms of gaining income from the wealth in the region, exceeding from the proportion obtained by other regions in Indonesia for its regional wealth, as regulated by Law No. 4 of 2004. The enactment of special autonomy is a golden opportunity for the people to govern themselves [7]. Special freedom is also expected to solve the problems in the Papua province, especially the issue of community welfare, not only aims to dampen conflicts [8][9]. Jakarta has a specificity because there is autonomy in the province as the direct implications of becoming the nation's capital. While DIY, it has a uniqueness as a monarchy that exists in a modern Republican state. In principle, the enforcement of special autonomy aims to encourage the development of each region faster with an institutional bureaucracy that adjusted local needs.

The critical implications of special autonomy in these five areas are the Special Autonomy (Otsu) Fund. The Otsus fund is a type of transfer to the region in the state budget, which is determined in a certain percentage of the national General Allocation Fund (DAU) and valid for a specified period. The Otsus Fund of Papua and West Papua is determined to be equal to 2 percent of the national DAU and is valid for 20 years (2002-2021). Meanwhile, the Otsus fund for Aceh is legitimate for 20 years (2008-2027), with the 1 st to the $15^{\text {th }}$. Annual allocation determined to be equal to 2 percent while the 16 th to the 20 th year is determined to be similar to 1 percent of the national DAU.

The Otsus fund was first allocated by IDR 1, 4 trillion in 2002 for the Papua province. The Otsus fund of Aceh Province began to be awarded in 2008 for IDR 3,6 trillion, while the West Papua province obtained the Otsus Fund in 2009 with an allocation of IDR 1, 1 trillion. During the period 2002-2018, the magnitude of the Otsus fund for all three provinces increased annually and has cumulatively reached IDR 142,5 trillion. On the other hand, the development of the welfare and economic indicators in the special autonomy area shows more improved access even though the improvement is not as fast as other areas. 
However, the highest poverty percentage was in the special autonomy area, including Yogyakarta. In addition to DKI Jakarta, which is the allocation of autonomy, especially the capital, either Aceh (15, 01 percent or six ranks), Papua (26.55 percent or position 1), West Papua (21.51 percent or rank 2) and Yogyakarta (11.44 percent or 12), the poverty rate is above the national. The Special Autonomy policy has been running in the four areas where it failed to reduce the poverty rate. Among the well-develop islands in Indonesia, Yogyakarta has the highest poverty rate in Java Island.

Special autonomy funds in Yogyakarta are called special funds. Since 2013 the Central government has been allocating Yogyakarta special funds to conduct its privileges. These privileges are a specific additional authority that is owned by Yogyakarta other than the power specified in the local government act. Yogyakarta's privileges continue to show an upward trend. In 2013, only reached IDR 115.7 billion but in the state budget (APBN) 2018 was increased to IDR 1 trillion. Therefore, the impact of special autonomy to poverty alleviation remind unclearly.

From the previous description, this article will analyze poverty concerning special autonomy program of Yogyakarta toward the utilization of special autonomy funds to reduce the poverty rate. This study is essential considering the purpose of granting special autonomy; one of them reduces the high poverty rate and providing an idea of whether the provision of the autonomy can accelerate the development and reduction of poverty figures.

\section{RESEARCH METHOD}

This research applied a qualitative method with a descriptive approach. The choice of this descriptive approach is to produce data in-depth and get a thorough picture of the problems that you want to solve through this study. The source of data was compiled from literature study derived from the journal, scientific report and various other documents produced by the relevant local government, Ministry of Finance, Ministry of Interior, BPS, World Bank, ADB. Secondary data is data obtained not directly from the data source, such as the realization report of the District's revenue and expenditure budget and privileges, the report of the special regional head of responsibility Yogyakarta, and other data that support this research.

The data analysis process begins with studying all the data that has been obtained from various sources. Then make the data reduction by way of making abstraction. The next step is to compile the data in units. The units are then categorized in the next level. The categorizing was done while creating the coding. The last step is to conduct data validity checks. After this stage is completed, then the newly performed interpretation of data so that the stages in qualitative data analysis included data unit processing, data reduction, data categorizing including data validity checks, and data interpretation.

\section{RESULTS AND DISCUSSION}

In this section, the article examined the features of poverty and special autonomy in

Yogyakarta and followed with the discussion on the regional government's effort to insert the poverty alleviation program under the special autonomy of Yogyakarta.

\section{Yogyakarta's Poverty Profile}


Yogyakarta is one of the provinces that has the highest poverty rate in Indonesia, at 11.44 percent or 448.470 people of Yogyakarta is below the poverty line [1]. The percentage of poverty in Yogyakarta is much higher than the national poverty rate of 9.78 percent. Moreover, the poverty rate was exacerbated by data on the population living in the poverty line of 321,056 people. (See Table 1)

Table 1. The Number of Poor Population in Yogyakarta Special Region in 2015-2019

\begin{tabular}{lccccc}
\hline \multicolumn{1}{c}{ District / City } & \multicolumn{5}{c}{ Number of Poor Population (Thousands) } \\
\cline { 2 - 6 } & $\mathbf{2 0 1 5}$ & $\mathbf{2 0 1 6}$ & $\mathbf{2 0 1 7}$ & $\mathbf{2 0 1 8}$ & $\mathbf{2 0 1 9}$ \\
\hline D.I. Yogyakarta & 550.23 & 494.94 & 488.53 & 460.10 & 448.47 \\
\hline Kulonprogo & 88.13 & 84.34 & 84.17 & 77.72 & 74.62 \\
\hline Bantul & 160.15 & 142.76 & 139.67 & 134.84 & 131.15 \\
\hline Gunungkidul & 155 & 139.15 & 135.74 & 125.76 & 123.08 \\
\hline Sleman & 110.96 & 96.63 & 96.75 & 92.04 & 90.17 \\
\hline Yogyakarta & 35.98 & 32.06 & 32.20 & 29.75 & 29.45 \\
\hline
\end{tabular}

Table 1 showed that during the 2015 to 2019 period, the percentage of poor people in Yogyakarta decreased from 14.91 percent to 11.70 percent. During this period, the number of low-income households in this province tended to decline gradually. In 2016, the percentage of poor people increased to 13.34 percent. Still, in the following period, the percentage of the population below the poverty line has decreased consistently for three consecutive yearspoverty reduction in D.I. Yogyakarta is thought to have a close relationship with the increasing economic conditions in Yogyakarta. In the first quarter of 2019, D.I. economic growth. Yogyakarta was recorded at 7.50 percent. This growth rate is higher than the economic growth in the first quarter and the third quarter of 2018 [1].

Moreover, in the last five years, the inflation rate in Yogyakarta was also relatively under control. In 2019, the D.I. inflation rate Yogyakarta was recorded at 0.60 compared to 2018. Also, annual inflation in March 2019 was recorded at 2.61 percent [1]. With controlled prices, the purchasing power of the poor can be maintained so that they can keep the level of population consumption.

The proportion of poverty is inequal between Yogyakarta city and the other four districts, where the city of Yogyakarta has a smaller number of poor people compared to other communities. However, from a regional perspective, rural and urban poverty in Yogyakarta showed different conditions, with the poor being mostly in urban areas. The number of poor people in urban areas was recorded at 304,000 people or more than double the number of poor people in rural areas of 143,000 people in 2019. However, the percentage of poor people in rural areas is more than in urban areas, the figure is 13.89 percent, while the poor in urban as much as 10.89 percent. Overall, in the last five years, the number of poor people in D.I. Yogyakarta has decreased by as much as 104.6 thousand inhabitants. During that period, on average, the number of poor people in Yogyakarta decreased by 8.04 thousand people per semester. The reduction in the number of poverties in D.I. Yogyakarta, which is quite significant, occurred from March 2015 to September 2015. At that time, the number of poor people decreased by more than 64 thousand people in one semester.

Yogyakarta Gini Index has stagnated around 0.42 in the last five years. This figure places Yogyakarta as the province with the highest Gini index in Indonesia. In general, the high rate of inequality can be reflected in the distribution of population expenditures. The poorest, 20 
percent of the population, spend only 5.66 percent of the total spending of the Yogyakarta population.

The calculation of the poverty line uses the average expenditure; the population with average spending below the poverty line is categorized as poor. The poverty line consists of the food poverty line and the non-food poverty line. The food poverty line is a representation of the minimum amount needed to meet basic needs for food and beverages, which is equivalent to 2100 kilocalories per capita per day. Meanwhile, the non-food poverty line shows the amount of money spent to meet basic needs other than food such as clothing, health, housing, education, transportation, telecommunications and other goods and services. Based on the results of the National Socio-Economic Survey in 2019, the amount of the Yogyakarta Poverty Line is IDR 432,026 per capita per month.

Food commodity contributes very significantly in determining the poverty line. In 2019, the Food Poverty Line of IDR 310,947 per capita per month added 71.97 percent to the poverty line. The poverty line in urban areas is recorded at IDR 452,628 per capita per month. Meanwhile, at the same time, the poverty line in rural areas was IDR 378,873 per capita per month. In general, the level of consumption of the population in urban areas is higher than the level of use in rural areas. This condition is also reflected in the poverty line, which is higher in urban areas than in rural areas.

In both urban and rural areas, rice provides an immense contribution to determining the poverty line. The gift of rice in urban and rural areas was 24.94 percent and 38.09 percent, respectively. Filter clove cigarettes are in the second position in the formation of the poverty line in urban (10.10 percent) and rural areas (7.58 percent). In urban areas, the next places for commodities that form the poverty line are eggs ( 7.31 percent), chicken meat (6.80 percent), and cakes (4.76 percent). Meanwhile, for rural areas, commodities that form the poverty line in the same position are purebred chicken (5.79 percent), eggs (5.78 percent), and tofu (3.71 percent).

As for the non-food poverty line, the five commodities that have the largest share in its formation are slightly different for urban and rural areas. In urban areas, the five products are housing, gasoline, electricity, education and health. Meanwhile, in rural areas, the five primary commodities determining the non-food poverty line are housing, gas, electricity, firewood, and toiletries. It can be seen that the products forming the non-food poverty line are dominated by goods whose prices are determined by the government, such as gasoline and electricity. Understanding the poverty line in Yogyakarta, local government should be able to provide more targeted policy interventions in alleviating poverty.

\section{Special Autonomy in Yogyakarta}

The special autonomy practised in Yogyakarta plays an essential role in the development and meeting public needs. Law Number 13 of 2012 concerning Yogyakarta as a special region provides flexibility in institutional development and better fiscal capacity with the existence of special funds. The implication of this special privilege encourages the regional government in Yogyakarta to optimize policies based on regional needs.

The Yogyakarta Kingdom (Ngayogyakarta Hadiningrat) existed in the middle of the 18th century. In the context of modern Indonesia as a republic, the existence of the Yogyakarta kingdom has a unique position. As one of the 34 provinces in Indonesia, the Kingdom of Yogyakarta is recognized for its power as an integrated monarchy in the republic system through the Sultan as the governor.

This status is due to the history of support and commitment to the integration of the Yogyakarta region since the early independence of the Indonesian republic. In late 1945, after 
the fall of Jakarta to the allies, the President and the cabinet moved to Yogyakarta. Thus, on January 5, 1946, Yogyakarta became the capital of the Republic of Indonesia. After the Indonesian capital returned to Jakarta in December 1949, Yogyakarta remained a special region.

In general, the dynamics of Yogyakarta as a special region occur in line with political changes in Indonesia. In 1948, the Central Government began to regulate local governments by issuing Law no. 22 of 1948 concerning the Basic Law on Regional Government which gave special autonomy to Yogyakarta. As a special region, Yogyakarta was formally formed by Law no. 3 of 1950 concerning the formation of the Special Region of Yogyakarta as amended by Law no. 19 of 1950. Both took effect from August 15, 1950, with PP. 31 of 1950. Law no. 3 of 1950 only consists of seven articles and an attachment to the list of autonomous powers. The law only regulates regions and capitals, the number of DPRD members, the types of authority, and transitional regulations. In the Law no. 3 of 1950 stated that Yogyakarta was a special region at the level of province, but to be called as a regional government.

Post-reformation, Yogyakarta faced Law no. 22 of 1999 concerning Regional Government which provides broader autonomy for all regions. Law no. 32 of 2004 concerning Regional Government, in lieu of Law no. 22 of 1999, gave a problematic position for Yogyakarta. As a special region led by a Sultan, Yogyakarta is faced with the need to have a regional leadership that must be directly elected through the election process. If in Law no. 22 of 1999, the election of the Regional Head was carried out through the DPRD so that the Sultan could gain legitimacy in an elitist way, then in Law no. 32 of 2004, the traditional ruler can no longer have these privileges. It is strange that to become a regional head, a king who is respected in his area must compete with the ordinary people for the top of local political power. If you win, culturally, it is not honourable, because he is a Sultan. If the Sultan lost, it would be very embarrassing. On the other hand, the people of Yogyakarta still have great respect for the Sultan as a traditional ruler and leader.

The power of the king even exceeds political, formal, cultural and social influence, but also material. Sultan Hamengkubuwono controlled a tremendous amount of land in Yogyakarta. Almost all public facilities, including government buildings, universities, sports buildings, markets, and rural areas, were used by the king, some without rent. It is difficult to imagine if the kingdom felt disappointed and decided to withdraw its wealth and set the lease backwards. Not only would the public administration in the regions experience difficulties, but the Central Government had to make substantial transfers to pay its obligations. The special status of Yogyakarta became a crucial issue until finally the issuance of Law Number 13 of 2012 concerning the Privileges of the Special Region of Yogyakarta. This authority includes procedures for filling the positions, duties and powers of the Governor and Deputy Governor, Yogyakarta Regional Government institutions, culture, land and spatial planning.

In exercising this exclusive authority, the central government through the Central Transfer mechanism allocates special funds sourced from the APBN to the DIY Regional Government. The central government has awarded privileges fund for DIY since 2013, whose number continues to increase every year. The total distribution of Privileged Funds for seven years (2013 to 2019) has reached IDR 4.34 trillion [10]. The fund that continues to increase every year is expected to encourage the Yogyakarta's regional government achieving good governance, community welfare, and develop its cultural heritage. 
Table 2. The Ratio between Regional Revenue and Special Fund in 2013-2019

\begin{tabular}{llll}
\hline \multirow{2}{*}{ Year } & Total Revenue & \multicolumn{2}{l}{ Special Funds (Millions Rp) } \\
\cline { 3 - 4 } & & Realization & Proportion $\%$ \\
\hline $\mathbf{2 0 1 3}$ & $2,583,056$ & 115,696 & $4.48 \%$ \\
\hline $\mathbf{2 0 1 4}$ & $3,139,871$ & 357,965 & $11.40 \%$ \\
\hline $\mathbf{2 0 1 5}$ & $3,400,014$ & 400,250 & $11.77 \%$ \\
\hline $\mathbf{2 0 1 6}$ & $3,899,192$ & 477,494 & $12.25 \%$ \\
\hline $\mathbf{2 0 1 7}$ & $5,085,241$ & 838,270 & $16.48 \%$ \\
\hline $\mathbf{2 0 1 8}$ & $5,443,179$ & $1,010,685$ & $18,56 \%$ \\
\hline $\mathbf{2 0 1 9}$ & $5,694,118$ & $1,221,604$ & $21,45 \%$ \\
\hline
\end{tabular}

Table 2 shows that the special funds received by Yogyakarta have increased over the past seven years. The ratio to total regional revenue has also continued to grow, namely $4.48 \%$ in 2013 to $21.45 \%$ in 2019 . This condition shows that special funds are one of the most significant contributors to regional revenue. Increasing fiscal capacity certainly increases spending capacity, one of which is for the welfare of the community. This issue is closely related to low-income households and their well-being in Yogyakarta that is relatively large. In this case, the local government has been trying to run a poverty alleviation program, including by inserting the program in the implementation of special autonomy financed with the privilege funds. The regional government's effort to add the poverty alleviation program will be discussed in the following section.

\section{Addressing Poverty under the Special Autonomy}

The special autonomy has often highlighted on its relation to people's welfare. One of the welfare indexes, such as poverty, showed that Yogyakarta in 2019 is the area with the highest poverty rate in Java Island, even exceeding the national poverty rate. Apart from poverty, inequality in Yogyakarta in 2019 is also the most elevated and exceeds the national figure. However, in the effort to develop the quality of life of the community as measured by the Human Development Index (HDI), Yogyakarta occupies the top position. With the allocation of the Privileges Fund for DIY that continues to increase, the thing that needs attention is whether the management of the Privileges Fund that has been carried out during the past seven years can bring Yogyakarta closer to the purpose of the Special Funds.

The central government's transfer to the regional government is financing the affairs of special autonomy to be conducted in Yogyakarta under the principle of 'deconcentration'. Although the Government of D.I. Yogyakarta carried out activities in the region; the programs of special autonomy belong to the central government in Jakarta. The Ministry of Finance and other related ministries are in charge of the Specific Allocation Fund (DAK) scheme to Yogyakarta. Every two year before the remaining year in accordance to the five affairs, the regional government has to propose programs financed by the special fund and provides reports at the end of the year to the Ministry of Finance. Consequently, the provincial government has to follow the regulation that the privileges funds can only finance the affairs of filling positions, duties and powers of the Governor and Deputy Governor, Yogyakarta Regional Government institutions, culture, land and spatial planning as seen in table 3. 
TABLE 3. The Allocation of Special Fund Based on Special Affairs

\begin{tabular}{lrrrrr}
\hline \multirow{2}{*}{ Allocation } & \multicolumn{5}{c}{ Special Autonomy Fund of Yogyakarta (Millions Rp) } \\
\cline { 2 - 6 } Culture & $\mathbf{2 0 1 4}$ & $\mathbf{2 0 1 5}$ & $\mathbf{2 0 1 6}$ & $\mathbf{2 0 1 7}$ & $\mathbf{2 0 1 8}$ \\
\hline Land & 210,347 & 356,314 & 169,458 & 420,926 & 373,489 \\
\hline Spatial Planning & 7,343 & 9,390 & 10,990 & 15,362 & 20,198 \\
\hline Institution & 52,636 & 110,312 & 349,523 & 323,559 & 555,340 \\
\hline Filling Positions & 1,344 & 1,476 & 1,700 & 11,032 & 12,517 \\
\hline
\end{tabular}

Table 3 shows that the allocation of special funds fluctuated as it connects to regional government priorities [10]. Also, it can be seen that the special fund was designed to finance only the affairs of privileges programs under the approval of central government which are not directly linked to poverty alleviation program. In 2014 and 2015, the highest allocation belongs to the culture affairs of IDR 210,347 billion and IDR 356,314 billion. However, the trend seemed to change because the spatial planning affair got more priorities by the regional government from IDR 349,523 billion in 2016 up to IDR 555,340 billion in 2018, for the land and institution were increasing even though they did not receive a higher allocation. Interestingly, there were several years without any special fund allocation on filling positions in 2015, 2016 and 2018. The distribution in 2014 was about financing the regional regulation on filing governor position in Yogyakarta. And, in 2017, there was allocation to fund the changing term of governor and deputy governor of Yogyakarta.

The changing priorities of regional government program on the privileges affairs have a connection with the effort to put the special autonomy as the leverage factor to people's welfare. The culture affair gained the highest allocation as it was providing some of capacity development program for the group and individual who ran small business and industry on traditional handicraft and art. Unfortunately, some of the programs have become cash transfer and lack of sustainability in 2014. The funds went to sponsor cultural events and festivals [11]. In 2015, the culture affair regained the highest allocation with a better preparation on the regional government proposal as it was proposed in 2013 or two years before the financial years. However, the problem of sustainability was reoccurring among the benefit recipients. This situation created a more substantial challenge on the special fund toward people welfare, primarily low-income household. Putting only culture affair program as the leverage factor seemed not yet to be successful.

In the following year 2016, up to 2018, the spatial planning affair attained the highest allocation as the regional government was focusing on providing better accessibility to both urban and rural area in Yogyakarta. The cases mainly worked to revitalize the spatial heritage of the Sultanate in which location are scattered throughout the region. Those spatial heritages comprises of the palace, traditional market, royal tombs and gardens, and other sacred areas that can be changed into tourism destinations and the centre of handicrafts. Connecting those locations with better access among different place, both urban and rural area allows more economical movement in Yogyakarta [12]. Similar to the problem under the culture affair, this spatial approach seemed to take more time to tackle the poverty problem in Yogyakarta. On the other hand, when the spatial planning was done, there should be a different priority to formulate under the special autonomy in absorbing the privilege fund and, also, prospering the people.

Understanding the challenge of special autonomy, the regional government was formulating a program to alter the regional government organization as a cultural institution. The Governor regulation no. 8 of 2016 about on the nomenclature in Yogyakarta Special Region 
has changed the terminology of official and its office form the region to the village levels. By altering it, the regulation transforms the organizational structure in Yogyakarta as cultural heritage which needs to revitalize and develop [13]. Consequently, in the future, capacity development to that institution becomes essential, and the privileges fund will be allocated to that program. Even though there is no direct connection to this program with the poverty alleviation, it will provide villages in Yogyakarta with a more significant amount of fund for the head of villages to manage and develop their area. As the village is spreading throughout the region, the privileges fund will be delivered to create development all over the regions as an integrated cultural entity. Again, the program acknowledges the regional government effort to benefit people's welfare with the special autonomy policy as the leverage factor to poverty alleviation.

However, measuring welfare based on education and health in the Yogyakarta Special Region is challenging as the region become one of the top areas with the highest HDI score. Then, tackling the poverty problem for better people welfare in Yogyakarta needs further effort. The regional government of Yogyakarta has induced the cultural value as the approach. This effort has nurtured the culture affair combined with other affairs to deal with the poverty issues.

\section{CONCLUSIONS}

This article aims to analyze poverty in Yogyakarta Special Region concerning the effort to reduce poverty rate toward the utilization of special autonomy funds. Based on the finding, the regional government added poverty alleviation program within the special autonomy activities designed and approved by the Ministry of Finance. Consequently, those programs utilized the special autonomy fund allocated to Yogyakarta. Related to poverty rate that is still high in Yogyakarta, programs funded with special autonomy funds are expected to provide a leverage effect to poverty alleviation. However, this leverage effect has not yet successfully appeared in the implementation of the special autonomy program in Yogyakarta. The regional government nurtures the effort to design some programs in tackling poverty problem under the special autonomy fund. Also, it will, hopefully, answer the classic question that arose related to the benefit of special autonomy to the people's welfare.

\section{REFERENCES}

[1] BPS, "Persentase Penduduk Miskin Menurut Provinsi 2007 - 2020," 2020. [Online]. Available: https://www.bps.go.id/dynamictable/2016/08/18/1219/persentasependuduk-miskin-menurut-provinsi-2007---2019.html.

[2] World Bank, "Indonesia overview," 2020. [Online]. Available: https://www.worldbank.org/en/country/indonesia/overview.

[3] S. Amartya, Poverty and famines. essay on entitlements and deprivation. Oxford, U.K.: OIT-Clarendon Press, 1981.

[4] S. J. Kakwani N, The Many Dimensions of Poverty. London: Palgrave Macmillan UK, 2013.

[5] A. de Janvry and E. Sadoulet, "Making conditional cash transfer programs more efficient: Designing for maximum effect of the conditionality," World Bank Econ. Rev., vol. 20, no. 1, pp. 1-29, 2006, doi: 10.1093/wber/lhj002.

[6] E. Fiszbein, Ariel; Schady, Norbert; Ferreira, Francisco H.G.; Grosh, Margaret; Keleher, Niall; Olinto, Pedro; Skoufias, "Conditional Cash Transfers : Reducing 
Present and Future Poverty," 2009. [Online]. Available:

http://hdl.handle.net/10986/2597.

[7] F. Joku, Problem and Prospectus of the Special Autonomy Law. University of Sydney, 2007.

[8] J. A. Mollet, "The dynamics of contemporary local-government policies and economic development in West Papua," Dev. Pract., vol. 21, no. 2, pp. 232-243, Apr. 2011, doi: 10.1080/09614524.2011.543273.

[9] C. Webb-Gannon, "Merdeka in West Papua: Peace, Justice and Political Independence," Anthropologica, vol. 56, no. 2, 2014.

[10] K. Zakiah, V. P. Lestari, S. D. Kirana, and H. D. Putra, "Akuntabilitas Dana Keistimewaan Daerah Istimewa Yogyakarta (DIY)," 2020.

[11] The Regional Government of Yogyakarta Special Region, "Performance outcome report," 2015.

[12] R. Anshori, "Dana Keistimewaan Yogyakarta Naik Rp 120 Miliar," Tagar.id, Nov. 11,2019

[13] B. Suryani, "Tahun Depan Danais Akan Lebih Mudah Mengucur ke Desa," Harianjogja.com, Dec. 17, 2019. 